draft, called Safety considerations for commercial and environmental applications of organisms derived by recombinant $D N A$, is so different as to be unrecognizable. In general, it plays down risks, and declares that its aim is to present "the maximum number of approaches a country might choose" to deal with safety considerations. It observes that "it is widely accepted that the hazards associated with recombinant-DNA-containing microorganisms may be assessed in the same way as those associated with other organisms", and concludes that "there is no scientific justification for singling out rDNA work for a special regulatory regime above that which is already established" for traditional biotechnology such as brewing. Residual concerns about predictability of field trials of modified organisms have been expressed "primarily by ecologists who generally possess no direct experience with rDNA or related techniques" and represent a minority opinion.

Dingell and Durenberger have written to Secretary of State George Schulz to ask that he get the OECD study "back on track". Many OECD countries are keen to have international authority for their regulatory approaches as soon as possible, and the 4-month delay brought about by the US shift has caused considerable irritation. But unless the FDA September draft is accepted, further delays are in prospect.

Tim Beardsley

\section{US-China nuclear deal} Washington

THE odds against congressional ratification of the nuclear technology pact between the United States and China became slightly greater last week, when Senator Alan Cranston, the Californian Democrat whip, threw in his lot with opponents of the scheme. Cranston believes that China is exporting nuclear technology to Brazil, Argentina, Iran, South Africa and Pakistan, the countries with the "most dangerous" nuclear programmes, despite China's pledge not to provide others with the means to develop nuclear weapons. He also asserts that Richard Kennedy, negotiator of the agreement, has deliberately withheld this information from Congress.

China acknowledges that it has peaceful nuclear cooperation agreements with Pakistan and Brazil, but denies a similar relationship with Iran. A statement from China's foreign ministry in response to Cranston's comments says that China's nuclear cooperation with any other country serves only peaceful purposes.

Cranston will help John Glenn (Democrat, Ohio) and others to draft legislation making China's acquisition of US nuclear technologies more difficult without firmer assurances on its non-proliferation policy. But Cranston admits that the chances of Congress rejecting the pact are still slim.

Maxine Clarke

US data protection

\title{
Privacy bill progresses slowly
}

Washington

MODERNIZATION of regulations on the privacy of electronic communications moved further forward last week, when representatives of the industries concerned endorsed the proposed legislation with only a few minor quibbles. The Electronic Communication Protection Act was introduced to both houses of Congress last month, and there will be a series of hearings during the next few months before the final version is drafted and voted on.

To coincide with last week's hearings, the Office of Technology Assessment (OTA) released a report, part of a study of the effects of new information technology on the federal government, which concludes that the technological revolution of the past 20 years has far outpaced laws to protect civil liberties. OTA's survey of 142 federal agencies shows that about 25 per cent of them use, or plan to use, electronic surveillance and that 25 per cent use computerized records.

The "wiretap" law of 1968 made telephone calls private, but the dramatic changes since then in communication electronic mail, cellular and cordless telephones, radio and video surveillance have no associated statutory protection. OTA's report spells out how information technology is affecting electronic communications, but does not grasp the nettle of the national security agencies' use of the technologies.

The new act would extend protection to virtually all electronic communications, eliminating the distinction between common and private carriers. It would also protect against unauthorized disclosure of third records, regulate the government's use of pen registers and tracking devices and create penalties for illegal access. But the difficulty is freely acknowledged of allowing for future development in an area that attracts the most daring entrepeneurs, and which is thus liable to explosive development.

Fred Weingarten, one of the authors of OTA's report, says nevertheless that the bill is an "important effort at addressing the potentially significant threat to the traditional privacy of communication". One of the quickest ways for an information service company to go out of business is to abuse the privacy rights of customers, says Michael Nugent of ADAPSO, the trade association for the US software and services industry. ADAPSO and the Telelocator Network of America, the national association of radio common carriers that produces cordless telephones and radio paging services, gave their support to the bill at last week's hearings.

Representative Robert Kastenmeier (Democrat, Wisconsin) and Senator Patrick Leahy (Democrat, Vermont), co-sponsors of the bill, hope to encourage the information technology market by assuring customers of protection as well as by providing comprehensive statutory protection from unauthorized surveillance. Until Congress passes some form of legislation, interim decisions have to be made in the courts, a time-consuming, expensive and unsatisfactory process.

It is to be hoped that the US law, when passed, will avoid the vagueness that has caused so much controversy over Britain's Data Protection Act, which has been widely criticized for the scope it provides for invasion of civil liberties (see Nature 307, 494; 1984).

Maxine Clarke

\section{Texas technology}

\section{Washington}

Texas, the Lone Star state which was briefly last century an independent republic, is once again displaying secessional tendencies, this time in the more limited domain of scientific research. The state legislature has recently awarded 87 grants worth $\$ 35$ million to Texan colleges and universities for scientific and hightechnology research likely to bring economic benefits to the state.

The Texas Advanced Technology Research Program was the initiative of state lieutenant governor William Hobby. Its approval was all the more surprising because Texas this year faced a budget crisis due to falling oil revenues, and some unheard of (for Texas) austerity measures were introduced. Supporters of the scheme argued, however, that falling revenues were all the more reason to support research of the kind likely to generate "practical sorts of things" for the state.

Support was provided for seven principal areas of research: aerospace, agriculture, biotechnology, chemistry and physics, energy, microelectronics and telecommunications, and materials science. Decisions on which applications to support were made by a panel of experts appointed from outside the state, headed by Dr Frederick Seitz, who among other things chairs the advisory committee to the Strategic Defense Initiative. When Seitz asked whether applied or basic research should be favoured, he was told just to choose "the best", according to a state official. The University of Texas and Texas A\&M University were the main beneficiaries.

Texas claims its scheme is unique in the country. The initial $\$ 35$ million is for two years, but the scheme will be continued if all goes well. It has, according to the Texas official, received the blessing of the National Academy of Sciences, whose chairman, Dr Frank Press, is said to regard it as a prototype of what might be achieved elsewhere.
Tim Beardsley 